УДК 069.15:379.8

DOI: $10.32340 / 2514-772 X-2020-1-49-52$

А. Л. Тимофеева

Алтайский государственный институт культуры (Барнаул, Россия) rp.mel@ya.ru

\title{
АСПЕКТ ИНТЕРАКТИВНОСТИ В ТЕАТРАЛИЗОВАННЫХ МУЗЕЙНЫХ ПРОГРАММАХ
}

Аннотация. В данной статье автор рассматривает связь между понятиями «интерактивности» и «театрализации» в общей структуре музейных программ. Целью работы является определение значения компонента интерактивности для театрализованных музейных программ. В публикации, автор анализирует сущность понятия «интерактивность» в значении - коммуникативного канала, а также суммы технических и информационных технологий. Так же, автор рассматривает сущность понятия «театрализация» в качестве творческого метода и коммуникативного канала, с которым затем соотносит термин «интерактивность». При работе над театрализованными музейными программами, автор предлагает считать интерактивность неотъемлемым компонентом театрализованных музейных программ.

Ключевые слова: интерактивность, театрализация, музейная театрализация, театрализованные музейные программы, теория музейной коммуникации.

В музейной практике направленной на работу с посетителями, широкое применение получили театрализованные программы. Особенностью данных программ является многокомпонентность, которая усложняет их понимание специалистами музейной сферы. Театрализованные музейные программы соединяют в себе элементы из области театра (деятельности режиссера) и музеологии, что требует более детального анализа роли «музейных» элементов в процессе подготовки и реализации подобных мероприятий. К числу таких элементов, можно отнести интерактивность, которая в современной музейной практике получила самое широкое распространение.

Цель работы - уточнить место компонента интерактивности в структуре театрализованных музейных программ. Цель поэтапно достигается через ряд поставленных задач. Первая задача заключается в рассмотрении сущности понятий «интерактивности» и «театрализации» в сфере музейной деятельности. Вторая задача, сосредоточена на анализе взаимосвязей компонентов относительно друг друга, на примерах различных музейных театрализованных мероприятий.

Анализ исследований позволяет согласиться с положением о том, что интерактивность стала неотделимым элементом современных музейных программ и экспозиций. Но, как отмечает в своей публикации Д. Шорина: «среди теоретиков и практиков отсутствует конкретное устоявшееся определение значения термина «интерактивность» [1, c. 52]. В своей работе Н. Никишин описывает актуальные подходы к пониманию компонента «интерактивности» [2]. Сторонники первого подхода понимают интерактивность как средство комму- никации. Автор отмечает, что смысл, вкладываемый в термин за последнее время значительно изменился. Если изначально музееведы предполагали сложное понятие «субъект-субъектной» коммуникации между посетителем и музейным предметом, подразумевающее «погружение» посетителя в определенную символическую среду, то на сегодняшний момент термин трансформировался в представление о простом тактильном контакте между собеседниками невербального диалога. Процесс коммуникации максимально упростился.

Второй подход к пониманию термина «интерактивность» заключается в том, что под данным компонентом подразумевают сумму информационных и компьютерных технологий, которые направлены, прежде всего, на расширение информационного поля музея внутри виртуальных сетей. «В музеях нового поколения уровень интерактивности стал измеряться не количеством экспонатов, открытых для прямого тактильного контакта, а объемом относящейся к этим экспонатам дополнительной текстовой и аудиовизуальной информации» [2, с. 41].

Отметим, что мнение музееведов относительно необходимости внедрения интерактивности в музейную практику разделилось по двум направлениям. Первая группа выражает опасение о том, что компонент интерактивности «приводит к снижению культурно-символического потенциала музейных предметов» [2, с. 42]. Но, существует и другая точка зрения о влиянии интерактивности на музейную деятельность, которая обосновывает необходимость включения данного компонента в работу музейных учреждений: «Современному 
музейному гостю, как показывает практика, недостаточно только выставок и описывающих их экскурсий для длительного и постоянного посещения музея» [3, с. 123]. Современный мир функционирует на основе различных высоких технологий и музей как неотъемлемая часть этого мира обязан интегрировать в свою деятельность наработки техники. В. В. Мингалев несколько резко высказывается о «высокой» миссии музея: «Вера в то, что настоящий предмет оказывает какое-то значительное влияние на формирование культурных ценностей - миф», но приведенная цитата может служить отражением стремления музейных специалистов расширить своё влияние на аудиторию за счет новых средств, в том числе и технических $[4$, с. 57$]$.

Обратимся к следующему компоненту театрализованных музейных программ - театрализации. Среди музееведов нет единого мнения относительно понимания сущности данного термина, поэтому рассмотрим основные подходы. Вопервых, театрализация - это творческий метод, направленный на реализацию сценарного материала под любое сценическое пространство специфическими выразительными средствами театра [5]. Данный подход утвердился среди специалистов в сфере режиссуры, но в теории и практике музейной деятельности он имеет ограниченное число сторонников. В большинстве исследовательских работ, театрализация понимается как своеобразный канал коммуникации, из-за чего понятие «театрализации» лишается исходного значения и ставится в один ряд с любым другим «каналом» связи музейного специалиста с его аудиторией. Необходимо отметить, что театрализация имеет коммуникативную составляющую но, в таком случае, по мнению автора данной работы, корректней было бы считать театрализацию универсальным каналом общения, который на основе выразительных средств режиссуры (в число которых может входить компонент интерактивности) позволяет аудитории коммуницировать с музейным предметом. Среди музейных программ можно встретить упоминание о такой форме музейного мероприятия как «интерактивное театрализованное представление» [6]. Определение составлено несколько некорректно, поскольку театрализованные сценические постановки изначально несут в себе элемент интерактивности, который является частью более крупной театрализации.

Размышляя о театрализации, необходимо перечислить выразительные средства режиссуры. К данным средствам относят как отдельных исполнителей (актёров) так и целые театрализованные группы, световое оборудование, звуковую аппаратуру, декорации, реквизит, и многое другое. И как уже было отмечено, в том числе, к выразительным средствам можно отнести и компонент интерактивности. В качестве первого примера внедрения интерактивности в театрализованную музейную программу рассмотрим сценарий дня рождения в музее «В чертоге подземного Короля», который был сочинен автором статьи для Музейновыставочного центра г. Когалыма (ХантыМансийский автономный округ). На данный момент, сценарий программы ждёт своей реализации.

Экспозиционно-экскурсионная деятельность музея повлияла на формирование замысла сценария. Так, ведущими мероприятия стали персонифицированные силы земли, а начальная часть программы проходит в самом необычном месте Центра - «зале истории нефти», комнате с интерактивной частью пола, ступив на которую посетители совершают своеобразное «путешествие» к основанию земного ядра, для ознакомления с процессом зарождения различных природных ресурсов. Интерактивный напольный экран за счёт мультимедийных технологий наглядно демонстрирует гостям музея строение земной коры. Но, автор программы придумал новую цель посещения зала, отталкиваясь от сюжета сценария. Посещение данного зала является обязательной частью программы мероприятия, поскольку, таким образом - «погружаясь в недра земли», экскурсионная группа попадает в покои подземного короля, роль которых исполняет соседнее выставочное пространство. В данном сценарии интерактивные технологии гармонично вписаны в общую канву ивента. Более того, исключение описанной части действа существенно понижает эмоциональное воздействие на его участников.

Во втором примере, приведено включение интерактивного компонента в действие театрализованной программы в качестве дополнительного коммуникационного канала. Как было отмечено, для элемента интерактивности наиболее характерным является способ вовлечения аудитории через тактильное (непосредственное) взаимодействие участников экскурсии с музейными предметами. Д. Агапова раскрывает работу интерактивного элемента музейной программы на примере выставки для детей: «Отсюда следует интерактивная экспозиция, на которой дети могут примерить лапти, попробовать как работает мельница, ступа, невод и т.п. Эта стратегия «приобщения» к культуре прошлого пользуется большой популярностью, поскольку соединяет традиции с современностью наиболее очевидным образом - через память» [7, с. 9]. Обрисованный принцип интерактивности был реализован автором данной работы при подготовке и проведении мероприятия на базе Алтай- 
ского государственного института культуры в рамках международной акции «Музейная ночь-2017». На площадке (включавшей достаточно широкий пандус с крыльцом), перед корпусом института была организована работа интерактивной выставки предметов народного быта «Мифология рядом». На ступенях пандуса были расставлены пять подставок, представляющие собой большие деревянные кубы, на каждой из которых выставлялся музейный предмет, относящийся к концу девятнадцатого - началу двадцатого века. К каждому музейному предмету был прикреплен индивидуальный аниматор. Работа выставки была подчинена сценарно-режиссерскому ходу - путешествия во времени. Аниматоры, приставленные к музейным предметам, были облачены в костюмы футуристического стиля и согласно замыслу режиссера, являлись музееведами-путешественниками из будущего. А пространство выставки - это точка пересечения прошлого, настоящего и будущего. Путешественники попадали в современный Барнаул через портал времени - часть декорации, которая должна была располагаться на верхней площадке пандуса-крыльца. Случайные прохожие с интересом входили в экспозиционное пространство, для знакомства с предметами прошлого через общение с людьми из будущего. Все предметы, которые были выставлены в экспозиции, можно (и нужно) было взять в руки, рассмотреть, опробовать в действии, сфотографироваться с ними. В рассмотренном примере театрализованной программы использование элемента интерактивности было «оправдано» за счет художественносмысловой составляющей представления, что заложило особый смысл в тактильное взаимодействие аудитории с выставленными предметами.

В качестве ещё одного примера музейного учреждения, в практике которого достаточно часто используется компонент интрактивности, выступает школьный этнографический музей «Мир русской деревни» (Мокеевская средняя школа, Ярославского муниципального округа), который проводит так называемые «интерактивные инсценировки», в основу, которых положены обычаи и обряды Ярославского края [8]. Названия инсценировок отражают использованный этнографический материал «Первый выгон скота», «Обряды и обычаи связанные с мукомольным делом», «Похороны кукушки и кумление», «Капустницы» и другие. На представлении, его участники выступают наряженными в стилизованные крестьянские костюмы. На импровизированной сценической площадке можно наблюдать натянутый полотняной задник, оформленный при помощи красок. В инсценировке используется тематический реквизит, в том числе подлинные музейные предметы, с которыми могут взаимодействовать зрители. В представленном примере участники инсценировки поимо обрядовых действий, реконструируют элементы народных игр. Как отмечает П. В. Глушкова: «презентация традиционной игры в рамках экспозиционного пространства наиболее полно возможна посредством создания интерактивной экспозиции, основанной на взаимодействии посетителя с музейным предметом, его самостоятельном исследовании» [9, с. 72]. Можно предположить, что в подобных представлениях внедрение компонента интерактивности обусловлено необходимостью непосредственного вовлечения гостей мероприятия в народные игры и обрядовые действа.

Таким образом, можно сделать вывод о том, что интерактивность может являться частью театрализованных музейных программ, при соблюдении следующих условий. Компонент интерактивности должен так органично вписываться в действо театрализованной программы, что при его исключении качество проекта существенно понизится. Художественная образность представления и логика сюжета также делают включение интерактивных элементов действительно необходимыми и придают им новый смысл. Несмотря на критику интерактивности музейными специалистами, необходимо отметить, что грамотное использование данного элемента в канве театрализованных музейных программах способствует значительно большему привлечению зрительской аудитории.

\section{Список литературы}

1. Шорина Д. Е. Интерактивность конкурсных проектов как основа современной экспозиционно-выставочной деятельности российских музеев // Museum. 2018. № 1. С. 52-57.

2.Никишин Н. Об интерактивности // Музей. 2016. № 9. С. 40-44.

3. Блаженкова Ю. П. Современные интерактивные технологии в культурно-просветительской деятельности художественного музея (на примере Приморской государственной картинной галереи) // Искусство Евразии. 2020. № 3. С. 121-130.

4. Мингалев В. В. Интерактивный музей // Вестник Музея археологии и этнографии. 2014. № 4. С. 57-60.

5. Вершковский Э. В. Режиссура массовых клубных представлений. Ленинград, 1977. 72 с.

6. Псковский государственный объединённый историко-архитектурный и художественный музей-заповедник : [сайт]. URL: http://museum. pskov.ru/ (20.11.2020).

7. Агапова Д. Культура участия: миллионы диалогов // Музей как пространство образования: игра, диалог, культура участия. Москва, 2012. C. $8-20$. 
8. Гусейнова А. Г. Особенности интерактивных форм работы музеев образовательных организаций Ярославской области // Современные проблемы сервиса и туризма. 2016. № 2. С. 64-71

9. Глушкова П. В. Интерактивная экспозиция как форма презентации традиционной игры телеутов // Учёные записки (Алтайская государственная академия культуры и искусств). 2019. № 2. C. $70-73$.

УДК 793.3(571.150+571.14)(=161.1):377.1:008(571.150)

DOI: $10.32340 / 2514-772 X-2020-1-52-57$

Е. Н. Эйхольц

Алтайский краевой колледж культуры и искусств elena.eiholts@yandex.ru

\title{
ПЕРВЫЕ ШАГИ В ОСВОЕНИИ ПЛЯСКИ - ОДНОЙ ИЗ ФОРМ ФОЛЬКЛОРНОЙ ХОРЕОГРАФИИ
}

\begin{abstract}
Аннотация. Данная статья, посвящённая изучению и освоению такого жанра фольклорной хореографии как пляска, опирается на материалы полевых исследований в Алтайском крае, Новосибирской области и на многолетний опыт работы автора в Алтайском краевом колледже культуры и искусств по теме «Фольклорный танец». Статья может быть интересна руководителям фольклорных коллективов, студентам специализации «Народное художественное творчество», «Хореографическое творчество», преподавателям фольклорных отделений детских музыкальных школ и детских школ искусств, всем интересующимся русской традиционной культурой и фольклорной хореографией.

Ключевые слова: традиция, экспедиционные исследования, пляска, импровизация, координация, эмочия, копирование, мастерство, усвоение элементов, мышечное ощущение, пульсация, обучение, варианты исполнения ,традиционные наигрыши.
\end{abstract}

Каждый фольклорный танец по-своему интересен и сложен. Войти в мир танца не так просто как кажется. Любое произведение танцевального фольклора не сразу раскрывает символику жанра. Необходимо войти в ситуацию события, вдуматься в танец, вжиться в него, чувствуя, накапливая и передавая возникшую энергетику. Пришедшая к нам из глубины веков, пляска, так же как и хоровод, и народно бытовые танцы малой формы, относятся к основным жанром русского танца. Пляска открывает большой простор, как для индивидуального, так и массового творчества.

Секрет пляски состоит в том, что участник определённых ситуаций в календарно-обрядовых или семейно-обрядовых событиях не может всегда быть только зрителем. Наступает момент, когда происходит эмоциональный всплеск. Появляется потребность выплеснуть накопившуюся энергию в индивидуальном импровизационном танце и зритель становится участником-исполнителем. «Импровизация - характерная особенность русской пляски» [1, с. 13].

Пляска со своей виртуозной импровизацией красивейшая народная традиция. Она просто и естественно переходит от поколения к поколению - дети перенимают её у отцов, как те перенимали у дедов. Несмотря на то, что преемственность поко- лений в танце существовала всегда, плясуноввиртуозов в Алтайском крае встречалось мало. В селе Верх-Уймон Усть-Коксинского района жил мастер импровизационной пляски, о котором вспоминала Захарова Матрёна Лукинична, 1920 г. p. [2]. Однажды в споре он переплясал цыгана, тем самым освободил своё село от систематического нашествия цыганского табора. В. А. Липинская публикует информацию, полученную от сибирячки А.Е. Петровой, которая не одобряла новомодные манеры в танцах: «Сейчас танцуют готовы пол проломить. А мы танцевали - свечку на голову поставишь, не упадёт»[3, с. 173]. Переселенцы привезли в Сибирь «Товарочку» - пение частушек женской парой под гармонь и перепляс «дроби». «Пение сопровождалось плясками и дробным пристукиванием каблуками» »[3, с. 173].

Во время исполнения своего танца участники как бы «приглядываются», «присматриваются» к себе, ловят собственный отклик на танец. Исполнительское мастерство приобреталось постепенно, формируясь с самого детства. Из воспоминаний Сосниной Матрёна Григорьевна, 1931 г. р., уроженки села Песчаная Солонешенского района, на тот момент жительницы села Красный партизан Чарышского района: «При свободной минутке в школе, на переменке, обопрусь руками о столы, 